\title{
USE OF STATISTICS IN EVALUATION IN E-LEARNING SYSTEMS
}

\section{Soňa NERADOVÁ-Josef HORÁLEK}

Abstract: This article describes the relationship between probability of passing a test and the form of the test. The aim is mathematically express the statistical probability of passing a test fortuitously, without previous learning. The reason for this analysis is the expansion of e-learning on all educational levels.

Key words: e-learning, testing, probability.

\section{VYUŽITÍ STATISTIKY PŘI EVALUACI V E-LEARNINGOVÝCH SYSTÉMECH}

Resumé: Př́spěvek poukazuje na vztah mezi pravděpodobností a formou testování. Hlavním zaměřením článku je matematicky popsat pravděpodobnost úspěšného vykonání testu náhodným způsobem bez učení se. Důvodem tohoto rozboru je rychlý rozvoj a dynamické nasazování e-learningových systémů do výuky na všech úrovních vdělávání.

Klíčová slova: e-learning, testování, pravděpodobnost.

\section{1 Úvod}

21. století přineslo rozmach informačních technologií. Moderně vybavené počítačové učebny, kvalitní počítačové sítě a vysokorychlostní připojení $\mathrm{k}$ internetu již nejsou jen výsadou vysokých škol a specializovaných učeben, ale stávají se standardem na všech stř̌edních školách a většině základních škol. Navíc i velká většina českých domácností také disponuje počítačem a připojením $\mathrm{k}$ internetu. I tato skutečnost je jedním z důvodů, proč se e-learning stále častěji stává běžnou součástí výuky na všech stupních škol.

Systémy, které se pro tvorbu výukových systému používají, se dají všeobecně nazvat jako LMS systémy. K jejich vývoji se používají systémy LCMS, umožňující tvorbu jednotlivých kurzů dle standardu SCORM, kompatibilních s LMS.

Pořízení vhodného systému může být pro vzdělávací instituci velkou investicí, proto je při jejich výběru potřebné stanovit si kritéria, která by tento systémy měl podle [1] splňovat:

* Charakter zamýšlených kurzů, zda se bude jednat o kurzy krátkodobé, semestrální, vysokoškolské studijní programy nebo programy celoživotního vzdělávání. Jak se budou kurzy aktualizovat, zda budou certifikované nebo necertifikované, jejich nároky na bezpečnost apod.

* Cílové skupiny, pro které budou kurzy určeny, zda půjde o kurzy pro veřejnost nebo profesně zaměřené skupiny, limity počtu uživatelů atd.

- Charakter vzdělávací instituce, finanční prostředky apod.

* Nároky samotného systému na správu, administraci, technickou údržbu atd.

\section{Systém LMS}

Learning Management System (LMS) je řídicí výukový systém (systém pro ř́zení výuky), tedy aplikace řešící administrativu a organizaci výuky $\mathrm{v}$ rámci e-learningu.[2]

Jedná se o aplikace, které v sobě integrují zpravidla nejrůznější on-line nástroje pro komunikaci a řízení studia (nástěnka, diskusní fórum, chat, tabule, evidence ad.) a zároveň zpřístupňují studentům učební materiály či výukový obsah on-line nebo i off-line. LMS systémy obsahují velké množství modulů, které upravují chování systému vůči jednotlivým uživatelům, umožňují rozlišení rolí a rozhraní dle požadavků a potřeb jednotlivých institucí.

Za běžné funkce systémů řízeného vzdělávání můžeme považovat následující moduly:

* evidence a správa žáků

* evidence a správa kurzů

* katalog výukových kurzů a objektů

* správa studijních plánů

* evidence hodnocení žáků

* testování a přezkušování žáků

správa př́stupových práv 
komunikační nástroje

* autorské nástroje k vytváření výukových kurzů a objektů - LCMS

úložiště výukového obsahu

LMS aplikací je velká řada. Některé jsou profesionální, akademické a komerční, existují ale i zdarma dostupná opensource řešení. Jednotlivé aplikace LMS mohou navíc obsahovat systém pro správu obsahu (Learning Content Management System - LCMS).

Mezi nejrozšířenější LMS patří BlackboardTM, Adobe Connect, Fronter, eDoceo, z open source jmenujme např. Moodle, jehož obliba v posledních letech výrazně stoupá nebo JoomlaLMS, který je postaven na redakčním systému Joomla.

\section{Systém LCMS}

Pod termínem LCMS (Learning Content Management System) jsou označovány systémy, které slouží k vývoji elektronických kurzů a současně řeší týmový proces vytváření a údržby obsahu, který zahrnuje didaktické zpracování, tvorbu, sdílení, distribuci a změny obsahu za spolupráce znalců obsahu, didaktických pracovníků, tvůrců médií a programátorů.[3]

Systém LCMS by měl splňovat několik základních podmínek:[4]

* plnohodnotná tvorba obrazovek kurzu za použití formátovaného textu a grafiky

* podpora vkládání řady typů multimedií (obrázky, animace, videa, zvuky, simulace) známých formátů, měnění jejich vlastností a programování jejich interakcí s okolím

\section{podpora výukových strategií e-learning}

* prostředky pro programování reakcí na aktivity uživatelů, pohyb a změny vlastností objektů, vytváření simulací

týmový proces tvorby a úprav obsahu

* správa a znovu používání obsahu, sdílení, jednotlivých verzí, zamykání obsahu a zdrojů

dekompozice a kompozice obsahu na výukové objekty libovolného rozsahu

Výsledkem tohoto systému by měl být plnohodnotný kurz, který splňuje standardy SCORM a je možné ho nasadit do libovolného LMS systému.

Mezi nejrozšířenější systémy LCMS v České republice patři iTutor, další používané jsou TotalLCMS, Saba Learning Suite, Plateau LCMS.

\section{SCORM}

SCORM (Sharable Content Object Reference Model $=$ referenční model sdíleného obsahu) je nejdůležitějším a nejvíce respektovaným mezinárodním standardem pro e-learningové vzdělávání. Je to model, který vytváří a doporučuje sadu vzájemných technologických specifikací a směrnic vytvořených pro splnění vysokých nároků na vzdělávací obsah a systémy. Norma SCORM byla oficiálně vydána $\mathrm{v}$ lednu 2000, od té doby se SCORM stále vyvíjí a expanduje $\mathrm{V}$ závislosti na potřebách průmyslových odvětví, vládních institucí a akademických participantů.

SCORM [5] se zaměřuje na web/webová prostředí jako na základní platformy pro dodávku vzdělávacího obsahu. To se děje za předpokladu, že vše, co může být doručeno vzdělávanému prostřednictvím webu, může být snadno použito v dalších vzdělávacích prostředích, která kladou menší požadavky na prístupnost a sítovou podporu. Tato strategie eliminuje většinu vývojářské práce potřebné pro prrizpůsobení elektronického obsahu různým technologickým platformám, protože web sám o sobě představuje univerzální médium pro dodávku obsahu. SCORM (vybudovaný na základě existujících webových standardů) osvobozuje vývojáře a zaměřuje je na rozvoj efektivních vzdělávacích strategií.

Základní principy standardu SCORM lze shrnout do několika klíčových bodů:

* Př́stupnost - schopnost zpř́ístupnit vzdělávací komponenty (kurzy, moduly apod.) z libovolných míst tam, kde je internet.

Přizpůsobivost - schopnost upravovat komponenty individuálním a organizačním potřebám, času a výdajů spojených s dodávkou vzdělávacích obsahů.

* Trvalost - schopnost snášet technologický postup bez nutnosti redesignu a přeprogramování.

* Interoperabilita - schopnost přebírat vzdělávací komponenty vyvinuté $\mathrm{v}$ různých oblastech a používat je opětovně i na jiných platformách - např. mezi různými LMS.

Opakovaná použitelnost - flexibilita pro začleňování vzdělávacích komponentů v jiných aplikacích a kontextech.

Díky standardizaci SCORM mohou zákazníci využívat LMS a LCMS od různých výrobců a tyto systémy spolu správně spolupracují. 
Někteř́i výrobci dodávají jak LMS tak LCMS. Tyto systémy pak často společně nabízí vyšší integraci, než jakou umožňuje norma SCORM a přináší tak zákazníkům další výhody, kterých nelze dosáhnout spojením LMS a LCMS různých výrobců.[6]

\section{Otázky a testování}

Jedním z nejčastějších využití e-learningových je $\mathrm{k}$ prezentaci studijních materiálů i testování. Typy úloh, které lze sestavit můžeme rozdělit dle [7] do několika dobře známých skupin. Tím nejčastějším je dělení podle typu úlohy (položek testu). Ty se pak rozdělují dle:

Formy:

\section{Otevřené úlohy}

Mezi typy patří doplňovací úloha, klastr doplňovacích úloh, produktivní otevřená úloha $\mathrm{s}$ rátkou odpovědí a produktivní otevřená úloha s dlouhou odpovědí

\section{Uzavřené úlohy}

Mezi tento typ úloh řadíme dichotomické otázky (binary item), klastr dichotomických otázek, otázka s výběrem odpovědi (multiple-choice item), otázka s vícenásobným výběrem odpovědi (multiple-response item), přiřazovací otázka, otázka na uspořádání, porovnávací otázka

\section{Přechodné úlohy}

Tyto úlohy pak vznikají kombinací prredchozích typů.

\section{Cíle:}

* Na reprodukci.

* Na porozumění.

* Aplikační.

* Analyticko-syntetické.

Cílem je samozrejmě sestavit maximálně objekticní testy $\mathrm{s}$ vyváženými otázkami. Oblíbenou a často používanou formou testování studentských znalostí je forma testu s deseti otázkami. Každá otázka nabízí čtyři možnosti, přičemž jenom jedna je správně. Student, který má $60 \%$ správně tj. šest otázek zodpoví správně, testem projde.

Otázkou zůstává, nakolik je splněný test odrazem studentových vědomostí, a nakolik vstupuje do hry náhoda a pravděpodobnost. Pokud tedy vyjdeme $\mathrm{z}$ toho, že student žádné znalosti nemá a vezmeme čistě jen pravděpodobnost, že projde testem, tedy uhodne šest otázek. Tuto pravděpodobnost spočteme následovně pomocí binomické věty.

\section{Pravděpodobnost a testování}

Pokud tedy vyjdeme $\mathrm{z}$ výše zmíněného tvrzení, že student žádné znalosti nemá a vezmeme čistě jen pravděpodobnost, že projde testem, tedy uhodne šest otázek. Tuto pravděpodobnost spočteme následovně pomocí binomické věty:

$$
P(E)=\frac{\sum_{k=0}^{m}\left(\begin{array}{l}
m \\
k
\end{array}\right)\left(1^{m-k} * h^{k}\right)}{(1+h)^{m+l}}
$$

$k d e \mathrm{~m}+1$ je počet otázek,

m je nejvyšší počet tolerovaných špatných odpovědí,

$1+\mathrm{h}$ je počet nabízených možných odpovědí na otázku.

Pro tedy náš uvedený př́ípad po dosazení vyjde:

$$
\begin{aligned}
& P(E)=\frac{\sum_{k=0}^{4}\left(\begin{array}{l}
4 \\
k
\end{array}\right)\left(1^{4-k} * 3^{k}\right)}{(1+3)^{10}} \\
& =\frac{1+10 * 3+45 * 9+120 * 27+210 * 81}{4^{10}} \\
& =\frac{20686}{1048576} \cong 0,02
\end{aligned}
$$

To můžeme vyložit tak, že ze sta studentů, dva uspějí bez jakýchkoliv znalostí. Tento poměr se $\mathrm{v}$ př́ípadě, že budeme předpokládat velmi povrchní znalost změní o řád.

$\mathrm{V}$ testech se často objevuje následující konstrukce: dvě otázky jsou hodně vzdáleny od správné odpovědi a student je může vyloučit pomocí dedukce a minimální znalosti dané problematiky. Pro představu uvádíme následující prríklad testovací otázky obsahující téma ze základních znalostí matematiky:

Čemu se rovná $\ln e^{2}$ ?

a) $\pi$

b) 333

c) $2 e$

d) 2

Průměrný student bude vybírat správnou odpověd' z možností c a d.

Pokud vyjdeme $\mathrm{z}$ toho, že všech deset otázek má stejnou konstrukci odpovědí, pak můžeme spočíst pravděpodobnost složení testu takto: 


$$
\begin{aligned}
& P(E)=\frac{\sum_{k=0}^{4}\left(\begin{array}{l}
4 \\
k
\end{array}\right)\left(1^{4-k} * 1^{k}\right)}{(1+1)^{10}} \\
& =\frac{1+10+45+120+210}{2^{10}} \\
& =\frac{386}{1024} \cong 0,38
\end{aligned}
$$

To můžeme vyložit tak, že přibližně čtyři $\mathrm{z}$ deseti studentů projdou testem při minimálních znalostech. Toto číslo je poměrně vysoké a vynucuje si změny testovacích otázek, tak aby prvek náhody měl menší účast a test více odrážel znalosti studentů. Je možné toho docílit různými cestami napríklad více otázek, více odpovědí. Další možností jsou takzvané přímé otázky. Pokud by $\mathrm{z}$ deseti otázek dvě byly př́mé a student $\mathrm{s}$ minimální znalostí na ně správně neodpoví a předpokládejme, že minimální znalosti mu pomohou omezit výběr na dvě možnosti. Potom pravděpodobnost, že úspěšně složí test, vychází následovně:

$$
\begin{aligned}
& P(E)=\frac{\sum_{k=0}^{2}\left(\begin{array}{l}
2 \\
k
\end{array}\right)\left(1^{2-k} * 1^{k}\right)}{(1+1)^{8}}= \\
& \frac{1+10+45}{2^{8}}=\frac{56}{256} \cong 0,22
\end{aligned}
$$

Pro tento př́pad je pravděpodobnost úspěšného složení testu studentem s minimální znalostí ještě poměrně vysoké číslo (jeden z pěti).

Pokud by $\mathrm{z}$ deseti otázek tři byly prímé a student s minimální znalostí na ně správně neodpoví a předpokládejme, že minimální znalosti mu pomohou omezit výběr na dvě možnosti. Potom pravděpodobnost, že úspěšně složí test, vypadá následovně:

$$
\begin{aligned}
& P(E)=\frac{\sum_{k=0}^{1}\left(\begin{array}{l}
1 \\
k
\end{array}\right)\left(1^{1-k} * 1^{k}\right)}{(1+1)^{7}}= \\
& \frac{1+10}{2^{7}}=\frac{11}{128} \cong 0,09
\end{aligned}
$$

Zde jsme řádově na stejné hodnotě jako $\mathrm{v}$ prvním vyčíslení $(\mathrm{P}=0,02)$.

Výsledkem je, že konstrukce otázek musí být taková, že všechny čtyři alternativy se jeví studentovi s minimální znalostí jako rovnocenné nebo je užitečné použít př́mé otázky.

Pokud budeme mít test obsahující deset otázek a ke každé pět odpovědí, potom pravděpodobnost, že úspěšně složí test, vypadá následovně:

$$
\begin{aligned}
& P(E)=\frac{\sum_{k=0}^{4}\left(\begin{array}{l}
4 \\
k
\end{array}\right)\left(1^{4-k} * 4^{k}\right)}{(1+4)^{10}}= \\
& \frac{1+10 * 4+45 * 16+120 * 64+210 * 256}{5^{10}}= \\
& \frac{62201}{9765625} \cong 0,006
\end{aligned}
$$

Je patrné, že lze výše uvedenými způsoby omezit tzv. náhodné natipování odpovědí. Tyto testy používáme ve studijních oporách a slouží jako zpětná vazba pro studenty, aby viděli, jak se orientují v základních pojmech daného tématu. Také je nutí k soustředění a pozornému čtení. Pochopitelně postupně jak narůstá počet probraných témat, tak narůstá obtížnost a proto je důležité přesné pochopení otázky pro výběr správné odpovědi. $\mathrm{S}$ podobným způsobem testování se studenti potkají, pokud chtějí získat odborné profesionální certifikáty např. v oblasti operačních systémů - Microsoft nebo počítačových sítí - Cisco.

Nicméně tento styl ověřování úplně neprověří schopnost analýzy zadané úlohy např̀ řešení, proč zařízení $\mathrm{v}$ počítačové síti nefunguje předepsaným způsobem. Dobrou prípravou pro zvládnutí takových situací je ověřování znalostí studentů pomocí kognitivních map[8].

Je patrné, že všechny výše popsané způsoby ověřování znalostí jsou neoddělitelné a vytvárí pro studenta prostředí, které mu nastavuje zrcadlo jeho skutečných znalostí.

\section{Závěr}

Problematika testování, tvorby objektivních testů a jejich vyhodnocení je problematika, kterou se zabývají odborníci nejen $\mathrm{z}$ oblasti didaktiky jednotlivých oblastí, ale i informačních technologií a matematiky. $\mathrm{S}$ nástupem informačních technologií do oblasti vzdělávání pak četnost využívání testů $\mathrm{k}$ hodnocení studijních výsledků narůstá. Tento článek chtěl poukázat na základní problémy s kterými se každý pedagog setkává při tvorbě a vyhodnocení testů a upozornit na jejich možná negativa. Dalším cílem tohoto článku bylo poukázat na 
nutnost kombinace jednotlivých typů otázek právě k vůli jejich větší objektivitě.

\section{Literatura}

[1] VANĚK, Jindřich. E-learning, jedna $\mathrm{z}$ cest $\mathrm{k}$ moderním formám vzdělávání. V Karviné: Slezská univerzita v Opavě, 2008, 96 s. Studia Oeconomica. ISBN 978-807-2484-713. [2] ČSN ISO 690 (02 0297). Praha : Český normalizační institut, 1996. $32 \mathrm{~s}$.

[2] Learning Management System. In: Wikipedia: the free encyclopedia [online]. San Francisco (CA): Wikimedia Foundation, 2001[cit. 2012-03-26]. Dostupné Z: http://cs.wikipedia.org/wiki/LMS

[3] LCMS. In: Kontis: e-learning [online]. [cit. 2012-03-26]. Dostupné z: http://www.elearn.cz/uvod_soucasti_lcms.asp?menu=elearnin g\&submenu=soucasti\&subsubmenu $=\mathrm{lcms}$

[4] Learning Content Management System. In: Wikipedia: the free encyclopedia [online]. San Francisco (CA): Wikimedia Foundation, 2001[cit. 2012-03-26]. Dostupné z: http://cs.wikipedia.org/wiki/Lcms

[5] The Sharable Content Object Reference Model (SCORM). In: [online]. [cit. 2012-03-26]. Dostupné z: http://www.netuniversity.cz/elearning/17-the-sharable-contentobject-reference-model-scorm

[6] Vztah obsahu, LMS a LCMS. In: Kontis: e-learning [online]. [cit. 2012-03-26]. Dostupné z:

http://www.e-

learn.cz/uvod soucasti vztah.asp?menu=elearnin g\&submenu $=$ soucasti\&pos $=6$

[7] ANDERSON, Lorin W, David R KRATHWOHL a Benjamin Samuel BLOOM. A taxonomy for learning, teaching, and assessing: a revision of Bloom's taxonomy of educational objectives. Complete ed. New York: Longman, c2001, 352 s. ISBN 08-013-1903-X.

[8] USING MIND MAPS IN TEACHING COMPUTER NETWORKS. Journal of Technology and Information Education: Časopis pro technickou a informační výchovu. 2011, roč. 3, č. 2, s. 3. ISSN 1803-537X. Dostupné z: http://www.jtie.upol.cz/clanky_2_2011/neradova. pdf

\section{Ing. Soňa Neradová}

Mgr. Josef Horálek

Katedra softwarových technologií

Fakulta elektrotechniky a informatiky

Univerzita pardubice

Studentská 95

53210 Pardubice 2

Česká republika

Tel: +420 466037004

E-mail: sona.neradova@upce.cz, josef.horalek@upce.cz, Www pracoviště: http://www.upce.cz/fei/kst.html 